\title{
ELECTRON MICROSCOPIC STUDIES ON THE MACULA STATICA
}

By

\author{
H. UEMATSU
}

\section{From the Department of Oto-Rhino-Laryngology, Osaka University Medical School}

(Director: Prof. T. Hasegawa)

Electron microscopic and partially histochemical studies on the macula utriculi were conducted in the normal guinea pig. Several of main findings are as follows;

1) The otolith crystal consists of a number of the fine granules with high density.

2) Between the otolith ${ }_{j}^{2}$ crystals and under neath the otolith layer, there is colloidal substance which shows positive reaction to P.A.S. staining.

3) The sensory hair of a sensory cell consists of a kinocilium and 60 70 stereocilia, and these cilia end in the colloidal substance under neath the otoliths.

4) So called "Cuticle" of the sensory cell is reticular structure wnich is the basal part of the stereocilia and is composed of many fine fibers. The intracellular portion of the axial filaments of the stereocilia situate in the networts.

5) Near the surface of the sensory epithelium, there are well developped terminal bars, which surround the sensory and supporting cells and form the reticular membrane.

6) Two kinds of nerve endings are distinguished. Most of them belong to so called nerve calix. in which nerve fiber maks basket-like endings around the sensory cell. The other type is budshaped one.

\section{平衡斑の電子顕微鏡的研 究 \\ 大阪大学医学部耳率呕㫿科教室 (主任: 長谷川高敏教授) \\ 植菘治雄}

\section{I. 緒 言}

前庭迷路の 形態学的研究は, Retzius ${ }^{29)}$ (1881) 以来 Kolmer ${ }^{17), W i t t m a a c k}{ }^{46)}$ なと゚によつてなされてきた。 しかし前庭迷路は，愲性迷路内にありことに平衡斑は 耳石結晶を含さため, 組織学的研究に困難が多く, 不明 な点も多い。

近年電子顕微鏡（以下電瀕と略す）の発達执よび，そ の医学一の応用の進步飞之毛ない，これら前莛迷路に打 いても, Wersäll \& Engström ${ }^{43)}$ (1953) のコルチ器 の電顕的研究老初めとして，彼等抢よび Sjöstrand ${ }^{8)}$ Smith ${ }^{35)}$ 36) 37) が, コルチ器, 膨大部棱, 平衡斑につい て，電顕的研究を行い，感覚毛の微細構造をはじめ多く の新らしい知見をもたらした。しかし平衡斑について の. Wersäll, Engström \& Hjorth ${ }^{43)}$ (1954) 扎よび Smith ${ }^{86)}$ (1956) の二つの研究は，耳石膜を除去した標
本についてなされ，耳石結晶と感覚上皮の相互関保につ いては観察されていない，革石結晶の構造については， Reibisch ${ }^{19)}$ (1899) 以来魚類については, その年輸梯層 棈造が涬告されているが，化の動物については，耳石結 晶の内部構造沉ついての形態学的研究は見ら就い，又 耳石結品之感覚上皮上の相互関傒化ついても, 光学影 微鏡（以下光顕之略与）的研究に上り, Retzius 28), Kolmer ${ }^{17)}$, Wittmaack 46), Werner 42) などが，稞ネ 論じているが定説を得ていない。

著者はこれらの点を含め，平衡斑の微細構造を明らか

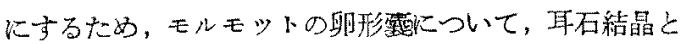
々もに卵形整全尿の超薄切片定作製し, 電顕的钼察を行 ot.

\section{II. 材料ならびに方法}

\section{1) 実鍳動物}


実駩に江体重 400 gr 前後のモルモツトを便用し，そ

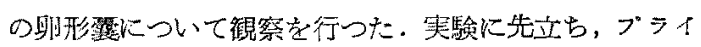
エル反射，跳躍準備反射お上び 20 秒 10 回転後眼震を検 查し，前庭迷路機能の正常なことを確めてから実呀に使 用した。耳石結晶就よび耳・石間物質研究には，参考のた めに一部䔲と蛙を便用した。

2）材料作製方法之镍察方法

(a) 電子顕徽鏡標本の作製方法之観祭方法

モルモツトをメーテル麻酸下に断頍し，軟部組鐡を除 去して側頭骨を取り出し，中耳骨胞を開くと〉もに双 眼ルーペ下に, 前庭を開いて卵形露を露出し, 直ちに Palade 法氛 による1\%オスミック酸ベロナール楥衡

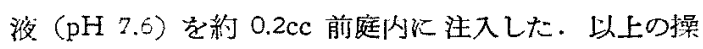
作を3分間以内に行い，2〜3 分後卵形霹が、黑褐色儿固 定されたのを確かめ，卵形要你凹にそつて切線を加えて

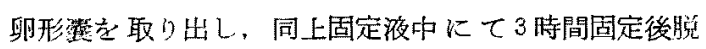

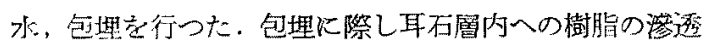
充分にするため，浸透時間は 2 昼夜以上とし，n-ブプ ル・メタクリレはとメテル・メタクリレイトの比を $7: 3$ ない 6:4 とし硬、標本走作つた。起薄切片作製 はライッ・ウルトフミクロトームにダイヤモンドナイフ を用らることにより，耳石結晶と感覚上皮をともに超 薄切片と乙心，電顕は電子工学 JEM 5G，日立製作所 HU 10, 明石慗作所 TRS 50 を侯用し, 直接倍率 2,000 × 30,000×にて観察した.

(b) レプリカ作製之観察方法

耳不結晶の立体ならびに表面構造篗察のためにレプリ カを作製した。双眼ルーブ下にモルモット, 罴, 址の沺

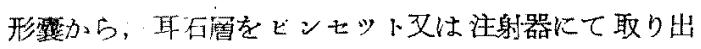
し，スフイドダンス上に作つたポりビニールアルコール 脱上儿整洙し，以下二段レプリカ法に従い，クロームで シャドウインダを行つたものを, 電顕にて 2,000〜 5,000 メにて䧺察した。

\section{(c) 光学影微鏡的観察方法}

耳石結唱就よび耳石問物質に対しては，切片ならびに 一部涂洙標本について, 組織化学的 ${ }^{90)}$ (P.A.S., Sudan III, Sudan black 染色) に観察した。

\section{III. 観察所見}

\section{1) 耶石層}

(a) 耳石結㖼

耳石結唱はレプリカ像 (写真 1)で, 六角棱柱状を呈 し，乙の大きさは大多数のものが数 $\mu \sim 10$ 数 $\mu$ で一部 数 $10 \mu$ の巨大な耳石が見られる，一個の耳石結晶は，
側面を6つの長方形で六角柱状に困をれ，先端部は六角 錐状でなく，相対する2面が汪ら゙屋根状以相接し，その 雨側の扔のおの二面は三焦形を呈するが，全体としては ほぶ六等稜柱に近い、レプリカ像では秷線が少し月味を おびているが，耳石表面は平滑で稜線の不整も認められ ない，耳石結晶の大小は，横径より哂径において著明に 認められ，大きな耳石結晶は細長い結晶として見られる ことが多い。

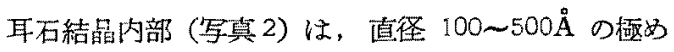
て電子密度の高い微細顆粒が，極度に密集した像を呈す る、この顆粒は耳石結晶内に，活ら゙均一下分右している が，一部には中心辺において周辺部より集合状態の粗な 像の見られることもある・オスミック酸固定を施した䅺 本の臂顕像では，耳石結晶を包艺膜様構造は認められな ᄂ.

(b) 耳石間および耳石下物質

耳石層下部值堡 $0.5 \sim 1 \mu$ の不整形の整状ないしは 小胞状の構造 (写真 3) が見られることがある。この構 造は周縁部が比䡥的電子密度が高く，その内部に電子密 度の低い均一な物質があり，元の中央部にや」晸子波度 の高い綱状ないしは網状の構造が見られるものが多い，

耳石結晶間执よび耳石結晶と感覚上皮との間には, 電 子密度の低い均質な物質が見られる(写真 4 )、標本によ つては一部索状ないしは網状を呈することすある，組織 化学的には, 耳石結晶間执よび耳石結晶下には, P.A.S. 陽性を呈する物質が認められ, Sudan III, Sudan black 陰性を示す。この P.A.S. 陽性物質と, 電顕で見られる 均一な耳石間物質は，同一のるのであるらと考光られ る。

感覚毛はこの耳石下物質中を耳石瘖へ走り，耳石結晶 下でこの物質中に終る(写真 4). 感覚上皮と耳石結晶間 に朕様構造は認められない。

2) 感営細胞

感覚細胞は感覚毛を有する表画，や〉紐くなつた頸 部, 円柱状の体部, 円い底部加らたり, 神経終末の形態 から 2 稉類を区別できる。多くのものは神経終末部が盃 状ないしは指状を呈して，細䑦底部から頸部を包むいか， 为る nerve calix 43) 43) を作るか゚，一部には棉状ないし は蕾状の神経終末が，細胞底部に接するものを認める。 神経終末の形態から二種類の感覚細胞を区別できるが， その内部桪造には差違は認められない。感覚細胞は卵形 覇周辺部では，感覚毛のない卯子状上皮の如き形態を示 すいわゆる过縁上皮細胞 ${ }^{29)}$ に移行する。 
(a) 細 胞 質

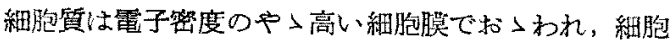
脱は紐胞表面に近い所で，その厚さ和よび電子密度を增 乙閉敛堤在形成する（写真 16，17）。感觉細胞上部心見 られる閉鎖堤は，支持細胞上部のものに比し，愿さ无薄 く内部構造も認め難い，細胞質には均質な基質の中に，

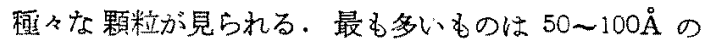
電子密度の高い顆粒で, Palade 顆粒 23) と考兄られる.

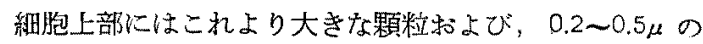
類円形の極めて電子密度が高く内部構造の認められない 脂肪顆粒之考えられる顆粒が小数見られる。細胞表面で 細胞の一側に偏して，感覚毛と平行に $5 \times 3 \times 3 \mu$ 位の細 胞質の指状突起が見られる（写宾 11）。この突起は練胞 膜か方連続した膜で和つわ机，その部の細胞質は他の部 訨汇比して電子滵度が低く，小数の顆䊉を認めるのみ で，小胞体や料站体は全く認められない。stereocilia 44) の中, この㔖起优近い2 2 3本のるのは, cilia の外 慕が指状笑起と連続し，指状笑起内に stereocilia の線 䊒様構造を認めることがある(写真 5，11)。細胞下部で 神経終末に按する部分には，小肘様構造が見られる（写 真21).

(b) 米粒体 (写真 12,13，14，21，22)

米粒体は $0.5 \times 0.8 \mu$ 前後の棈円形を呈し，他の組韵に 見られると同様な二重朕構造に囲まれ，内部に基質と cristae mitochondriale が認められる. cristae は一 般には米粒体の短径にほ心平行に，多くは米粒体を完全 に横断するように排列する。米粒体ははら゙細胞全域に見 られるが， stereocilia 基底部㵊も多数集合し（写悬

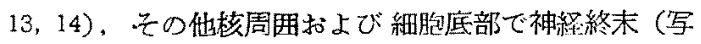
真 21，22）之接する附近に3〜数個集合して認められる. stereocilia 基底部直下に集合する禾粒体は，他の部分 のものに比しや入大で, cristae の断裂, cristae の減 少, cristae の消失などの像が見られる。このように糧 種変形した糸粒体が多数見られるが，この場合も二重臊 構造は明らか訆められる. kinocilia 基底部には、こ れに反し米粒体注とんど認められない（写真7，8）。 stereocilia 基底部附近のもの以外では, 上述の如变变 形した系䊀体は認められない。

(c) 小胞体 (写真 12,23 )

感覚細胞の小胞体は主として, 粗面小胞体であり, 滑 面小胞体は時として核側部に認められるのみである。

粗面小胞体梳長き約 $2 \mu$ で，電子密度の高い外圓と， それに囲まれた靕子密度の低い中層とからなり、外層の
外側には $150 \AA$ 位の電子滵度の高い顒粒が排列主る。 粗面小胞体は核下部には2 3 個平行に並んで認められ゙ 核側部で珐坬立性に認められることが多い，

核側部汇は最大 $4 \times 0.5 \mu$ の大きさを有し，電子密度 のや高い限界朕に困委机内部電子密度の低、滑面小胞 体が見られることか゚ある、この小胞体は形態お上び大き さが全く不整であり，細胞によつては認められないこと む少くない。

(d) エ゚ルデ野（写基 14）

ゴルデ野は卵形霓中央部より，周緣部の感覚細胞に著 明に認められる。細胞内で占める位置は核上部に限ら れ，ことに cilia 基底部の下 $2 \sim 4 \mu$ の籍囲に数個集合 して認められる。卵非婯中央部では，最大 $0.7 \times 0.02 \mu$ の管状構造と，微細な胞体および顆粒が集合して，1x $1 \mu$ 程度のゴルデ野が形成され，数個所にや小散在して 認められる．この部分の感覚細胞のゴルデ野では，㵔明： な空胞は認められない，卵形烈周辺部に近つくく従い， ゴルデ野は著明となりゴルデ層板，ゴルデ顆粒、ゴル ヂ小胞および胞体む明らかとなり，核上部の橫断像では ほとんど細胞全域をゴルず野が占めるような像が見られ ることがある。

(d) 核 (写真 21,22 )

核は約 $8 \mu$ の活ざ円形を呈し，細胞の底部に近く存在 し，通常小さな裁痕を1個有し，核小体は1個認められ る. 核実質は支持細胞泉核に比しや〉電子密度が低い

（e）感党毛打よびその基底部

1 個の感覚細胞から出る感覚毛は，60７0本の ster-

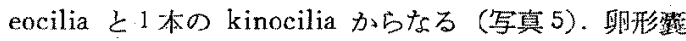
周辺部では 60 本前後の stereocilia の及で kinocilia は 認められない，1個の感覚細胞から出る cilia は, 従断 像でははよ゙平行に，横断像では汪が六肩形に規則正しく 排列集束する. kinocilia，stereocilia，とも直経的 $0.2 \mu$ のけ柱状で，細胞脱と同じ薄い被朕を有する。Ciliaは， 耳石下物質中を，垂直に耳石層一走り，耳石下物質中心 終るが，途中 cilia の融合，分枝などは認められない (写真4). kinocilia は外償に和〉われた電子密度の低 い基質内に，電子激度の高い 9 本の filaments が被膜 の内側同一円周上に，規則正しく排列乙， cilia 内で 平行に走る。線毛上皮の kinocilia ${ }^{10) 14)}$ と見られる上 らな，一対の中心性 filaments は認めることができな かつた（写真 5). kinocilia は常に細胞の指状乫起部に 近く偏在し，その基底部では.9本の filaments が, 横断 潒で霜事状に連り stereocilia 起底部を作る網状構造部 
记は独古に更に澡い基底小体を作る（写真9）。基底小 体の周囲には，相当広い籍田にわたり電子密湜の高い微 細顆粒が多数認められる（写点 7). 基底小体から中央 客り $0.7 \sim 0.8 \mu$ D所に，基底小体と垂直面上で更に $90^{\circ}$ 距つて中心小体を認める (写壹8).

stereocilsa は感賞細胞素面から出古所では，や小組 く (值径 $0.1 \mu$ ) 次第に太くなり直堡 $0.2 \mu$ となる, cilia 基底部 $0.5 \mu$ と細胞外部 $0.7 \sim \mathrm{I} \mu$ の箸度には, cilia $\sigma$ 中心部に1本の電子密田の高い軸糸を㤎める。それより 上部では cilia 内部は全体として微細䠌維栐を思わせ る像を示すが，明らかには認められなかかつた(写真6). stereocilia 注従来蓋板 (cuticle) と呼ばれている部 分から出る.この部は綎断像では，感覚稩胞裴面から約 $-0.5 \mu$ の嬮さの範囲に， $50 \mathrm{~m} \mu$ 以下の電子密度の高い顆 絃が集合し，この尿内に stereocilia 軦糸の起底部が垂

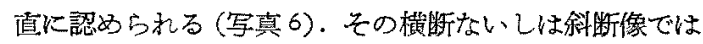

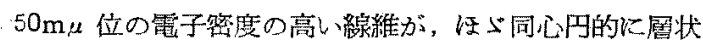
をなして走り，全体として絧状を呈し，線濰間に直径約

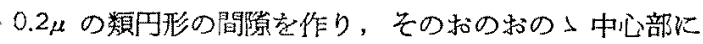
1 本つ〉 stereocilia 軸条の基底部を容れている（写真 9，10）.この絧状構造は，細胞質の指状突起の存在する 反対側に偏し，啮断像て感賞細胞の $1 / 2 \sim 2 / 3$, 時にはを れ以上の部分を占める。感筧細胞表面に近い所では，こ

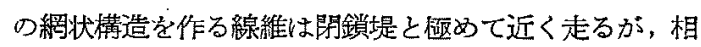
互間に線維の連络認められない，網状棈造はその下部 では，その線維が汪上んど細胞全周を四えでいるが，そ の場合でも細胞の一側に小くとも $1 \times 1 \mu$ の網状構造の ない部分があり，kinocilia 基底部が諗められる。 stereocilia 軸秝山細胞外部に出万時 $50 \mathrm{~m} \mu$ の太さを有する が, その基底部で法漸次その太さを減じ，細胞表面から

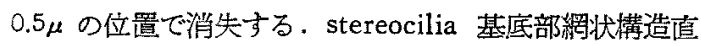
下には, 前述のごとく糸粒体が多数集合する (写真 13).

3) 支特細胞

支持細胞基底膜から感覚上皮表面まで達し，感覚細

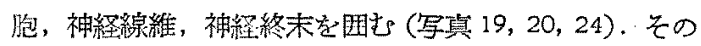
形態は不整であるが，基底暝に接する底部は任心゙平面的 であり，耳石層に面吉五表面は，全体として彭隆し，直

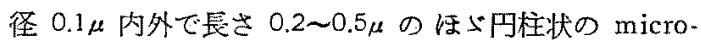
vili 老有专る (写真?).

細胞質は細胞底部では電子密度が檽めて近く，顆粒も 任とえど認められない（写真24）、核上部では細胞筫は

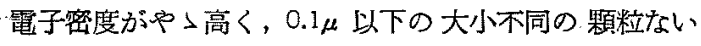
ししは小胞様楧造が多数見られ，細胞表面に近い細胞質内

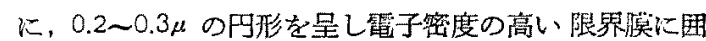
まれ，その内部に電子笜度の高い,微細顆粒の認められる 胞状体が見られる（写真 11，17）。核上部にはその他に

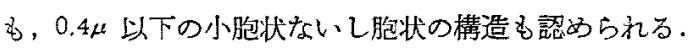

系精体忹感覚細胞のものに比しや小小さく, $0.5 \mu$ 以下 の秜円形で，核上部ことに表面に近い部分に諗められる (写真7)。この部分では感覚細胞の stereocilia 基底部 の下のもの上同様，米精体の空胞化户 cristae の眐烈像 が羿められる。

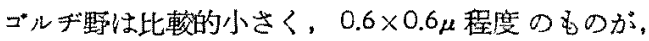
核上部に散在する。

感覚上没表面に近い所で，支持細胞と感覚組胞および 支持細胞相互が接する所で，細胞膜はその愿さと電子密 度を堌し，閉鎖堤を形成する。この部は横断像で，安持 細胞上部を全周にわたつて環状に取り丑み網状膜を形成

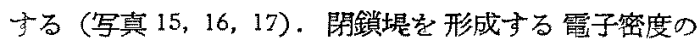
高い構造は場所以上りぞの愿さが異るが，最大 $2 \mu$ 位

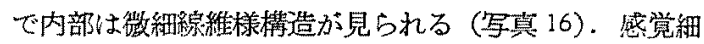
胞之支持細胞，支持細胞相互間の細胞間傹は，網状膜の 部分て横断像に和いて，波形圭呈し，間隐の狭い部之后

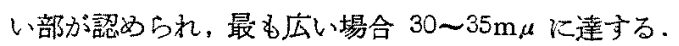

核性最大直径 $9 \mu$ の棈円形で，その長径は基底膜に ほ.‘值角で，基底膜に近く位置する，核実質は感覚細胞 の核より電子密度が高く，核小体を通常2個認める（写 瞽 $18,19,20,24)$.

(4) 神経䠌維拉上び神経終末

前庭神経の枝として入つた神経は，基底朕下に基底膜

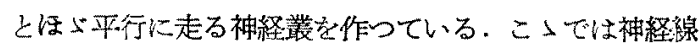
維は有䯣で，厚さ約 $0.3 \mu$ の留板楧造の見られるミェリ ン勒を有し，更にその外側にはシンワン氏細胞が見られ

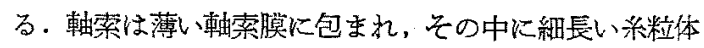
と, 神経走行に忹ら平行に走る細いneurofilaments 認められる。

基底膜を通る所で神経䠌維は，ミエリン靬を失い無随 となつて感賞上皮内人入り，更に分枝して支持細胞間を

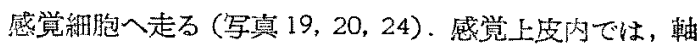

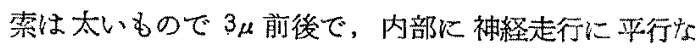
neurofilaments と僅加の絃体加認められる。軸索は

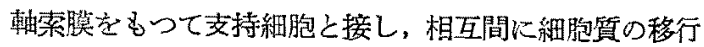
は認められない. 軸案内の neurofilaments は感覚細胞 に近づくに従い認め難くなる。

神経終末心その形態上，二種類を区別することができ る・第一の型は軸索が，その終条部で盃状に広がり，感 
推細胞の底部加率部にかけて包むいわゆる nerve

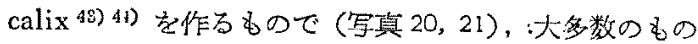
がこの型に属する，第二の型は神経終末部で桿状ないし は薷状となつて，感党細胞底部ないしは底側部に按する むので (写点 22), この琵に属するbのは嚾かである.

nerve calix を作るるのでは，軸索は感觉細胞底部に

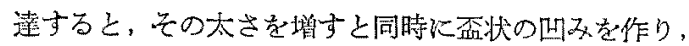

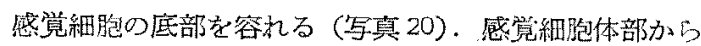
頸部にかかては，碱状となつた㜞索が指状はいしは樹枝 状となる．横断像では感覚細胞底部ては，韩索が同心円 的に，感當細胞全周を固んでいるが，上部になるに従、

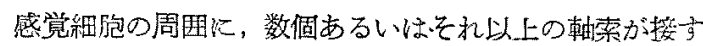

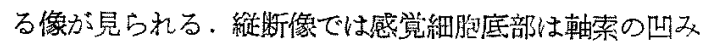
の中にあるが，側面では必ずしも全面を連秸して国ま

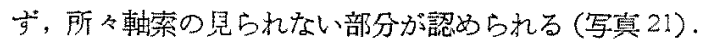

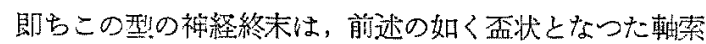
が面に先㙐で，指状ないしは樹枝状をなして感觉細胞を 包んでいると考光られる。神経終末部で感覚細胞と軸素 の接す石所で, 所々心感觉細胞に $0.5 \mu$ 前後の四みがて

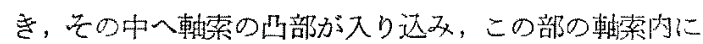
$0.1 \sim 0.2 \mu$ の円形の小胞状楧造加見られ，での附近によ り小さな小胞を認める。禾粒体は神経終末部では，感筧 細胞の縦軸に平行に排列し，一厤に感覚細胞を柬さ。一 万この部に相当する感覚細胞内にも，朶粒体が数個集合

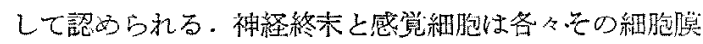

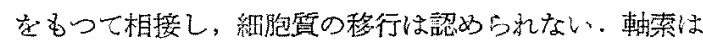

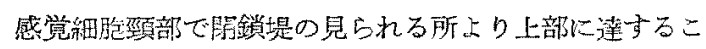

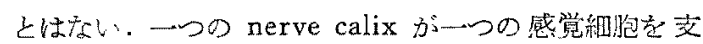

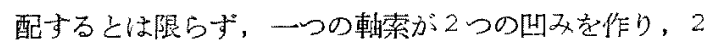
つの感覚細胞を容れる場合も諗められる(写奌 12,23).

第二の㑭飞执いては，神経軸索は感賞細胞底部ない儿

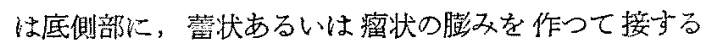
(写顛 22). 神経終末部には，多数の糸粒体が集合し， 微細顆粒と $500 \AA$ 以上の小胞状構造が見られ，相対す

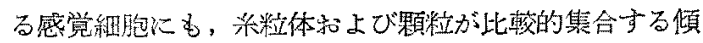
向が見られる。1個の感賞細胞にはこの上らな神絽終末 が2〜数值接している。この䍿の神絽終末にも，軸索と 感覚細胞の細胞留の移行は諗められない。

（5）基底脾枋よび基底膎下組織

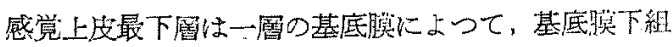
織亡分かたれている（写學 20，24）。基底膎の感览上皮 内への陌入像は認められず，神経軸萦のみに貫か子れてい

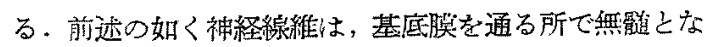

る. 基底膜下の有骮神経は, 值堡 $3 \sim 4 \mu$ のものと1〜

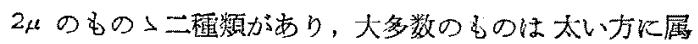

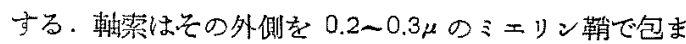
れ，ミェリン䩗には電子密度の高い圈と低い居の層板状

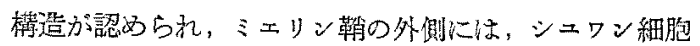
が認められる。1個のシニワン細配は1本の神経腺維を 包み，1個のシコロン細胞が多数の神経䠌維を包屯像仕 認められない，基底膜下には神経楾維，シニワン維胞の

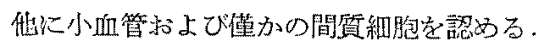

\section{IV 絵括ならび考按}

\section{(1) 耳 石 層}

Kolmer ${ }^{17}$ ) 等の記藏 の媢く，脊稚動物のいわゆる Macularium は, 有機性の耳石老保持するもの之, 钲譏 性の耳石結晶から成つている。耳石結唱は彷来光顕的に は、一マトキシリンに濃染する辺縁部と, 淡染する内部

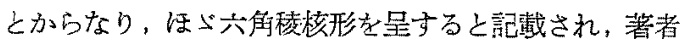

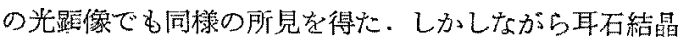
の内部棈造について休，Reibisch (1899) 以来 Ruysch， Werner 19)などが，魚類の耳石結晶は年輸梾尿構造を認 めた以外は，他の動物に执いては不眀である。舟周，辢

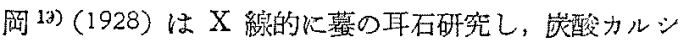
ウムは arragonit の結晶秀を示し，蛋白体に石死塩が 礼着して耳石結晶を作ると報告している。取結晶の発。 生学的砳究は, Wittmaack (1919), Kawano ${ }^{15)}$ (1922),

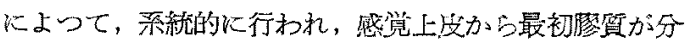

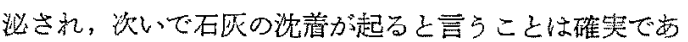
ららと考它ら机る。このことから耳不結昆が，単なる炭

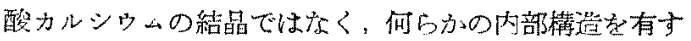
るのであららと推測できる。著者の行つたオスミック酸 固定安行つたモルモツトの耳石結晶の超薄切片の電频像 で，電子密度の高、微細顆粒が，電子泌度の底い基質 中に集合して認められ，対照として行つた白色ゴムの中 に炭酸カルシウムを封入したものつ超薄切片を電湿的に 観察しても，電了密度の高い玸一な像のみで, 耳石結晶 のような顆粒状構造は認わられない，又光顕像で区別で

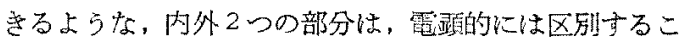
とができなからた。良つて光影の場合固定によつて，耳

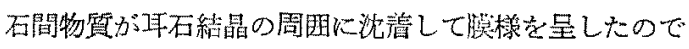

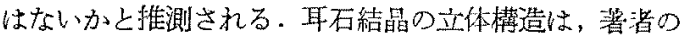
レプリカ法による麗显像で, 明に六角權柱形であること

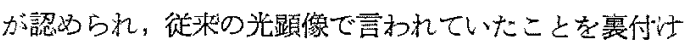
ることができた。

前述のごとく耳石層下部には，直径 $0.5 \sim 1 \mu の$ 琵性 
辚造が見られるが，これが耳石結晶之関俰のあるもの (例克ば耳石結晶の基となる路㥞物質)か，あるいは耳 石間物筫に関保あるすのかは不明である。

従来耳石間物筫の本態飞ついては，膨大部不，コルテ

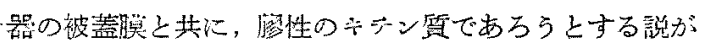

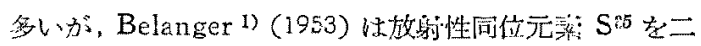

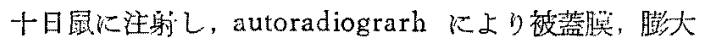
部頂，耳石間物質にS 25 を証明し，これらは sulfomucopolysaccharide からなるのであろうと述べ, 著者も

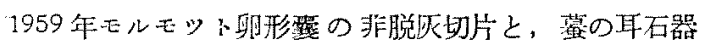
管の溒沫標本について耳石間物質が P.A.S. 陽性を示す ことを認め，次いで立木 (1960) も上記备位の P.A.S.

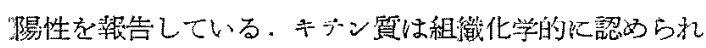

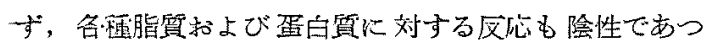
た。電顕的には耳石結晶間执よび耳石結唱と感筧上成と の間に，電子密度の但い、算構造な物質として認められ，

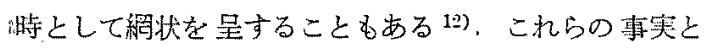
文苚から考按して，耳石を保持する物質は，膠様をなす 粘液多糖類恐らく sulfomucopolysaccharide はかららな ると考えられる。電影的に網状学呈したり，光影的に耳 石結晶の被㬴状を呈したりするのは, 固定に伴う人工变 化ではないかと考える。

(2) 感賞細胞

(a) 感 覚 毛

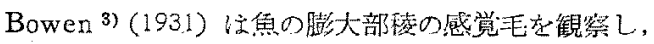

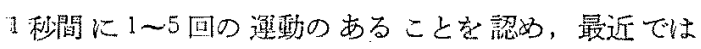
Löwenstein \& Roberts ${ }^{21)}$ (1949) が電気生理学的に,

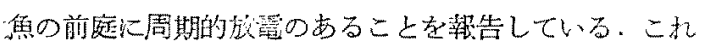
ら生理学的研究からも湔庭感觉上没に綜乗があるのでは なかららかと考えられてきた。一方形態学的には，感覚 毛佂 kinocilia とをうでない細胞からの突出物がある ことは Fürst ${ }^{44)}$ が見仙し，Helb ${ }^{13)}$ (1909) は内年感 觉上发には腺毛があり，細胞質中の中心小体から出てい ると記戴している：電頻的には Wersäll 4H)(1956)が

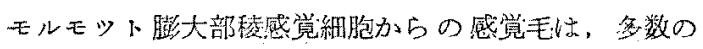
stereocilia とl本の kinocilia からなることを見出 している. 卵形露については Wersäll, Engström \& Hjorth 49) (1954) が, 感覚毛は1 列に8 本づ〉5列に 並ぶ cilia があると記载しているが， sterecilia と kinocilia の区別てついては述べられていない渚者は

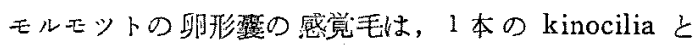
60 70 本の sterocilia からなり, 橫断像ではぶ六角形 に規則正しく策束するのを認めた。しかし卵形蒦周縁部
の感筧細胞では, 感覚毛に kinociliaを認めなかつた。 kinocilia については Fawcett \& Porter ${ }^{10)}$ (1954) か

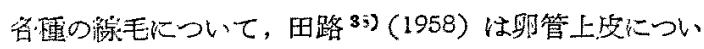
て、山本 ${ }^{47}$ (1953) 恜管粘朕について，猪术 ${ }^{14)}$ (1958)

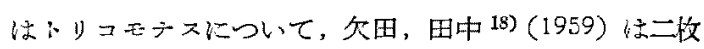
具のエラについて、それぞれ kinocilia について研究し， いづれも一対の中心性軸系と, cilia 周緑に规則正しく 排列する9 本の 周緑性軸系の合計 11 本の綜維構浩を認 めている，膨大部稜感覚細胞においても，Wersäll 44) (1956)は kinocilia に同様11本の軸杀が認奶られる

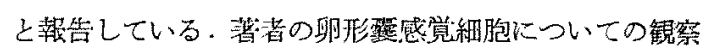
では，9本の周緑性軸治は䈉明に認められるか゚，印心軸 米は認めることができなかつた。著者の钼祭した籍田の みがら贸形刑感覚細胞の kinocilsa は, 中心軸糸を有

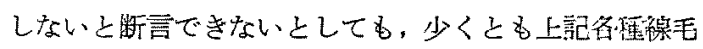
についての記戴のような箸明は中心朝糸を持たないこと

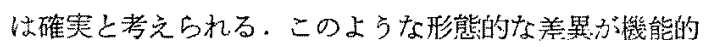

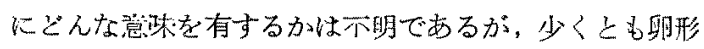
整の kinocilia は一投の楾毛の上うな著明な媈動性が

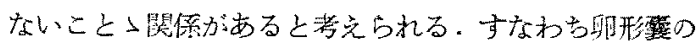
埸合 kinocilia は, stereocilia の支持補強儿㨽くもの ではないかと教える。

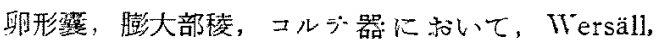
Engström 等は, kinocilia は stereocilia と同核感覚

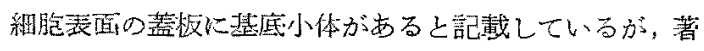

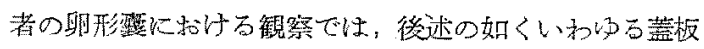
と言和れる部は， stercocilia 望底部立作る網状構造で あり，kinocilia は艺の部とは独立して細胞貿指状突起 部に近く确社する。基底小体の構造については，前述 Fawcett その低が，kinocilia は基底倪で中心軸糸を失

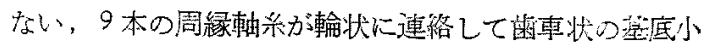
体を作ること学明かにしている。更に下等動物では，基 底円板および小根が認められることは，前述猪太ぶトり コーナスにおいて欠田, 田中が二枚貝のエシについて報

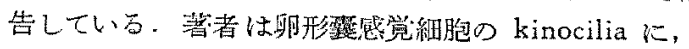
Fawcett 等の記戴と同様な齿底小体を認めた，基底円 㭘や小根は認めなかつたが，基底小体の周田に電子密度 の高い微細顆粒が多数あり，縦断像では stereocilia 基 底部絧状構造とよく似た像老示す kinocilia 基底小体 から $0.7 〜 0.8 \mu$ はないて，基底小体と垂直な面上で夏に $90^{\circ}$ 回転した位置に，基渲小体と同様菡事状楧造を持つ 中心小体様の構造が認められる。基底小体のの立体構造 については出路 ${ }^{35)}$ らの研究があり，基㡺小体が禬々の 
急度に届曲することが明にされているが，二つの平面上 に屈曲した基渲小体は幸告されていない，著者の場合の 二つの基底小体的よびそれと同様な構造は，山田，安武 47) (1958) が嗅粘膘上没で見た kinocilia 基底小体の近 くにある中心小体と同じような構造と考况た力が，二面 上に屈曲した基底小体と考学るより妥当であるらと思わ 机る。

stereocilia の内部構造については, Wersäll ${ }^{44)}$ がを の底部近くに一本軸系を認めているが，著者も同様中心 軸糸を基底部から，細胞外部 $0.7 \sim 1 \mu$ の範团飞認好る が，それより上部で中心軸の認妨れない部分において

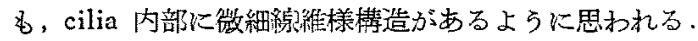
これらの構造は kinocilia と異ると同時に microvili や brush border とも異つている. Engström ${ }^{93}$ (1956) はコルデ器沉ついて, Wersäll 44) (1956) は膨大部棱に ついて, 中山 52) (1950) もコルテ器について感覚毛は, 感覚細胞表面の蓋板にその 基底部があると述べている

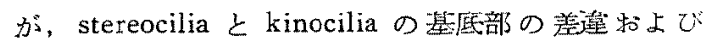
steriocilia 基底部については報告されていない，署者 の钼祭によ扎ば、い初る蓋板から出るのはstereocilia であり，前述の如く kinocilia は独立した 基底部を有 する.蓋板と呼ばれる部分は，旋断像では Engström \& Sjöstrand, Wersäll の言う如 $<, 0.5 \mu$ の厚さに細

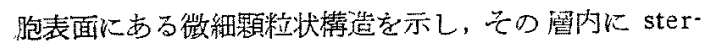
eocilia 軸系の基宾部が，基直に入つて米り，著者も同 様像を観察したが，その橫断沾よび斜断像では， $50 \mathrm{~m} \mu$

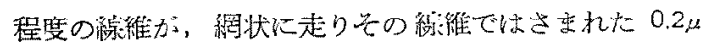

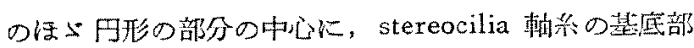

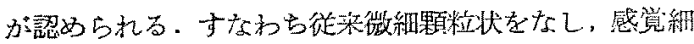
胞表面を覆うとされていたいかゆる盖板と言われる部分 は，stereocilia 基底部を楧成する網状構造である。こ のような楧造および網状構造下に系粒体が集り，来粒体 の変形が認められることなとから，感覚炕関与するのは stereocilia で, 各々の sterecilia からの刺㦸がその基 底部網状搆造で集合されて神経終末へ㐾達するのてはな いかと考えられる。

感覚毛終末については光㩆的に程々の説が市り， Retzius ${ }^{28)}$ (1881), van der Stricht ${ }^{42)}$ (1922), Kolmer 16) 17) $(1923 ， 1926)$ は，耳石償は支持細胞から分必され た膠様物質が㬝状をなしたもので，その中に垂直にある 空览の中を，感覚毛が上へ走りその中で遊離の状態で終 るとし Wittmaack 48)（1926）は感覚毛恃との上部で相 互に連絡し網状となりその最上部で耳石荧を作るとして
いる，先の他Werner 42) む及黑説をなし，定説を得て いない，落者の電顕像では，cilia 相互間に連絡を認め ず，耳石結唱下に㪇様構造も認められない。これ等の点 は，Kolmer の説とほ心゙同一所見であるが，耳石下下物筫 中に Kolmer の言うような等隐老認わることはできな かつた。この上らな cilia の状態からる, 平衡斑は

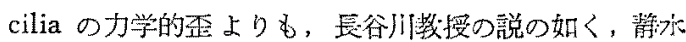
田の变化によく対応しらる形態を示していると考只られ 苛。

（b）紐胞内微細構造

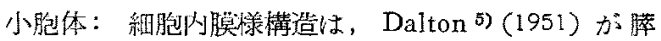
贜の外分泌細胞に批いて見出したのが最初で，その後各

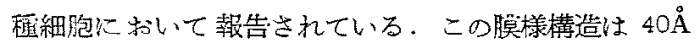
の膜で囲まれた管状棈造で, 号の外側に $150 \AA$ のリボ核 蛋白質の顆粒の見られる粗面小胞体と，顆粒の見られな い滑面小胞体の二稬頪が区別されている，その機能につ いては Palay 5) (1958), Siekevitg, palay \& palade

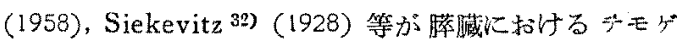

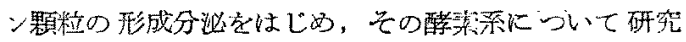

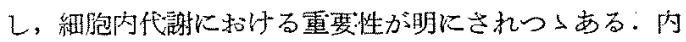
耳感覚細胞については、 コルダ器, 膨大部稜について, Engström, Wersäll が報告し，同様な粗面小胞体は卵 形感覚細胞の核下部に，2〜3個集合して認められた。 核側部に見られることのある $4 \times 0.5 \mu$ の内腔を有する 胞状構造は，Wersäll (1956) が言う上うに一般汇言方 れる意昧での滑面小胞体之呼ら゙のが適当がどらかは多少 皆問炕思わ机る。

米精体；米粒体の微稩棈造に関しては，Claude \& Fullan 4) (1945) をはじめ, Palade 23) (1952), Sjöstrand ${ }^{83)}$ (1953), Zetterquist ${ }^{50)}$ (1956) Бに上つてなさ

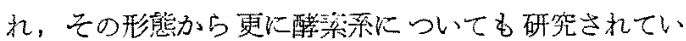

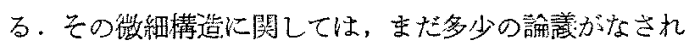
ているが，一般には二風の電子嘧度の高い朕とその閒に

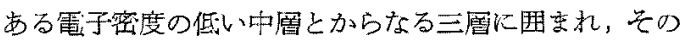
中に卦留とCristac を有与ると理解してもよいと考党

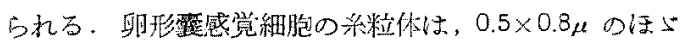
㮁円形であるが，その分布が主として stereocilia 基底 部直下で，この部に多数集合し形㓦む稫々变化したもの も認められる。禾粒体の種々な形態扰よで变性糸粒体に

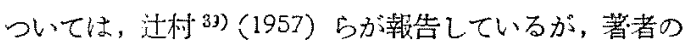
場合 stereocilia 基底部下の米粒体汇の灭空胞化，cristae の断裂，減少などを認めることは，前述の如くこ の部に执いて代謝が最も激しいことを示しているのでは 
ないかと考壳られる。

ゴルデ野；電影的にゴルギ野を钼察したのは, Dalt on (1951), Dalton \& Felix (1953) 等で, ゴルデ野 は 1) ゴルデ空胞，3）ゴルデ顆粒からなると述べられ ている.前庭については, 光㩆的に Cajal (1908) 和上 び Kawano ${ }^{15)}$ (1922) が核上部に1個のゴルヂ野を認

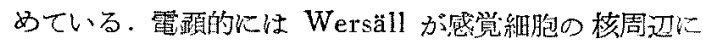

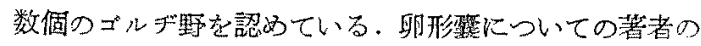
浣察では，ゴルデ野は核上部に限られ，数個のものが

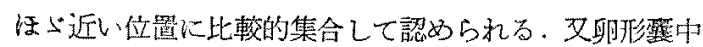

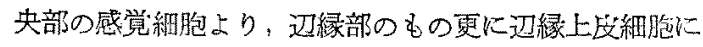
著明に認められる。このことは分泌と何らか心䦭係があ るのではないかと考完る。

(3) 芰持細胞

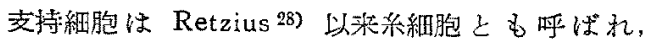
Werner 42) の記戴によれば，“文持細胞は感觉上皮全 層にわたり，基底膜がら表面まで垚し，底部にほડ゙棈円 形の核を有し，1〜3個の核小体がある，底部細胞部分 から支持鼣維を有する細い突起が表面に详し，そこで広 く強くなり，全体として網状膜を作る”とされている。 電影的には Wersäll が平衡班㧍よび膨大部稜について

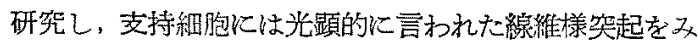

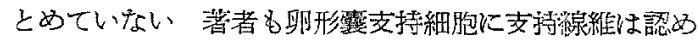
なからた。この点 Engström \& Wersäll 7) (1953) が ダイテル氏細胞に支持楾維を認めたのと相違がある。感 党上责表面に近い所で，感覚細胞も支持細胞も細胞膜は

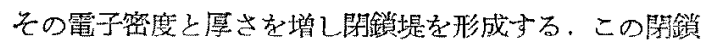

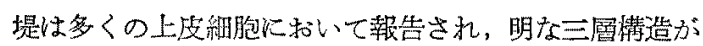
示されているが，眀形整の支持細胞では特にその発澾が 著明で 2 の厚さにも澾する. 閉鎖堤の部分を横断した 像では，細胞全周を取囲んでいるが部分的に発達の程度 が異り，Porter ${ }^{26)}$ (1954) がイモリの表段で観塞した Biszzero の結節に多少似た構造を呈する。文普通閉镍 堤の部では細胞間の間隔が狭いが，卵形䙵感筧上皮では

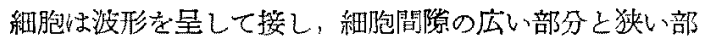

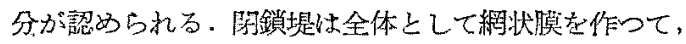

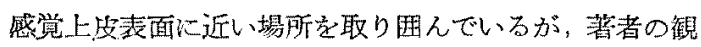
察所見からは，徒来言加れてきた支持のみでなく，威覚 上皮の上部と感覚上没間の登通路をなしているのではな いかと洘炎られる。

支持緗胞と神経腺維との関保は，コルデ器において Engström \& Wersäll 7) が，網膜に括いて Sjöstrand 33) (1953), 日中 ${ }^{99}$ (1959) が，昧篦に执いて Engström
9) (1956) מ゙, 又起大部稜に放いて Wersäll 44) (1956)

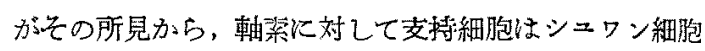
と同様な䟕係を有するのであららと述べているが，著者 の場含子同稼と考克られる。

Wersäll 43) (1954) は卵形形茠の支持細胞の表面に， balloon-shaped process と呵灾細胞質の突起を記載し

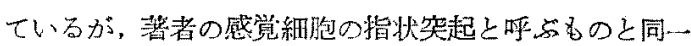
の乎のではないる考它る。

(4) 神終終末

神㹩接合部の櫣造が電顕的に明確に示されたのは， Reger 2\% (1955), Robertson 30) (1956) の端板にお㇒t

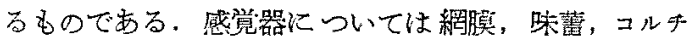

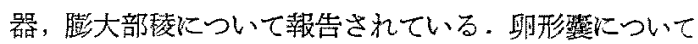

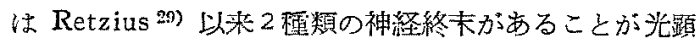
的に示されて和り, 電湿的にる Wersäll 43) 等が nerve calix と元らでない小さな神経終末を認め, 更にWer-

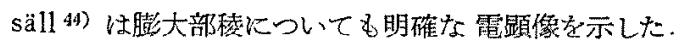

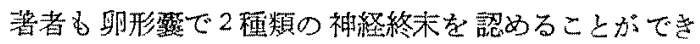
た. nerve calix は Wersäll が模型国でも示している ような，軸采が歪状になり感敩細胞を完全に包むので なく，感筧細胞底部では盃状であるがそれより上部では 推状ないしは樹枝状となり，感覚細胞を包む管のように

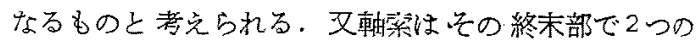
四在作り，2つの感覚細胞を作万場合す認められ，

Wersäll 等の記载する上うな軸察の分枝が支秲細胞間 のみで行われるものでないと考党られる. nerve calix には Palay 24) (1954) 等の記戴した synaptic vesicles と呼ばれるものは萻明には認的難いが，これは神経終末 と感覚細胞の接する面が広いこと入関倷があるのではな いかと考觉る。他の一つの舊経神経終末心 Sjöstrand ${ }^{33}$ (1953) が絧臊で，Engström 等がコルチ器で観察した ものとほぶ同様構造を示すこのよらに前庭と㯖器の神 経終末の形恝の違いは，感受する刺㧹の相違のみに基く 当のかどらか、明である。

\section{V. 結語}

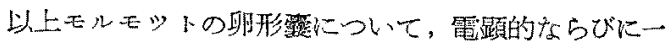

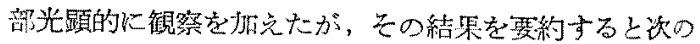
如くである。

1）耳石結晶は六质稜柱状をなし，内部は均一な基留 と微細顆粒からなる。

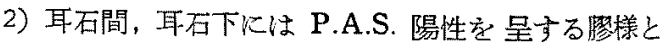
考えられる無構造な物質がある。

3) 感覚毛は 1 本の kinocilia 乙60 70 本 $の$ stereo- 
cilia からなり，集束し，耳石下物質中心終石、2 樯数 ○ cilia はとの起始部走異にする。

4) 従来蓋板 (クテクラ) と言われた部分は, steocilia 起始部を形成する網状構造である。

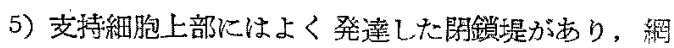
状膜を形成し感筧;細胞，支捎細胞定囲已。

6)神経終末は主として nerve calix を形成するが， 一部桿状ないしは蒥状を呈するものる認められる。

\section{主要 文 献}

1) Belanger: Science 118, 1953.

2) Bielchowski z. Brühl: Arch. mikr. Anat. 71, 1907. 3) Bowen: Proc. Nat. Acad. Sc. 1931. 4) Claude E Fullan: J. Exp. Med. 81, 1945. 5) Dalton: Am. J. Anat. 89, 1951. 6) Dalton E Felix: Am. J. Anat. 92, 1953. 7) Engström \& Wersall: Acta Otolary. 43, 1953, 8) Engström \& Sjöstrand: Acta Oto1ary. 44, 1954. 9) Engström: Ann. Oto. 1956. 10) Fawcett \& Porter: J. Morph. 94, 1954. 11) 長谷川：加速度病，1948. 12) 長谷川, 他: 綜合陪 床, 7, 1958. 13) Held: Untersuchung über den feineren Bau des Ohrlabyrinthes der Wirbeltiere 1909. 14) 猫木, 他: 寄生虫学雑誌, 7, 1958 . 15) Kawano: Arch. Ohrenhk, 110, 1922. 16) Kolmer: Arch. Ohrenhk, 116, 1926. 17) Kolmer: Handbuch der Neurolagie des Ohres 1923. 18) 炏田, 用 .中：電子㩆微鏡，7，1959，19）工藤，他：耳石，1951。

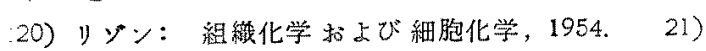
Loreecstein $\mathbb{6}$ Roberts: J. Phys. 110, 1949. 22) :中山: 日耳綉, 63, 1960. 23) Palade: J. Exp. Med. 95, 1952. 24) Palay: Anat. Rec. 118, 1955. 25) Palay: Frontiers in Cytology 1958. 26) Por ter: Anat. Rec. 118, 1955. 27) Regar: Anat, Rec. 122, 1955. 28) Retzius: Das Gehörorgan der Wirbeltiere Bd. I. 1881. 29) Retzius: Biolog. Untersuch. 1881. 30) Robertson: J. Biophy, Biochem. Cytol. 2 Suppl. 1956. 31) 濑戸：人の知觉, 1957. 32) Siekevitz: Ciba Foundation Symposium on the Regulation of Cell Metabolism $1959 . \quad 33)$ Sjöstrand: J. Appl. Phys.24, 1953. 34) Sjöstrand G Rhodin: Exp. Cell. Rec. 4, 1953 . 35) Smith: Anat. Rec. 121, 1955. 36) Smith: Acta Otolaryng. Suppl 126, 1956. 37) Smiih: Ann. Oto. 65, 1956.
38)田路：大阪方立大学医学雑䜅，7, 1958. 39) 由 中：最新医学，14，1959.40) 迁村：電子画微鏡，

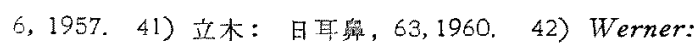
Das Labyriuth. 1940. 43) Wersäll, Engström \&3 Thjorth: Acta Otolary, Suppl. 116, 1954. 44) Wersäll: Acta Otolary, Suppl. 126, 1956, 45) Witmaack: Arch. Ohrenhk, 114, 1926. 46) Wittmaack: Arch. Ohrenhk, 116, 1926. 47) 山本: 気

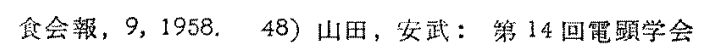
緮会予猫集, 1958. 49) Yokokama: Arch. Hist. Jap. 6, 1956. 50) Zetterqvist: The Ultrastructural Organization of the Colmner Epithelial Cell of the Mouse Intestin 1956.

\section{写真 説 明}

第 1 図两石結鼠レプリカ像

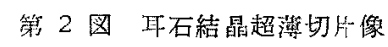

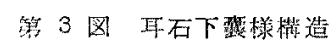

第 4 间 耳石結暃之感喾毛の相互関绿

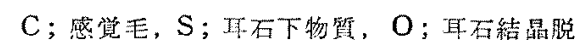
落像

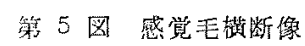

$\mathrm{K}$; kinocilia, S; stereocilia, $\mathrm{F}$; 感覚細胞 指状突起

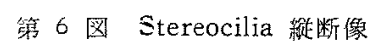

$\mathrm{S}$; stereocilia, A; stereocilia 中心耤䒺基,

$\mathrm{R}$; stereocilia 虚部編状精造

第 7 图 kinocilia 基店小体 (B) 鰂䉼像

算8 图 kinocilia 壆底小体 (B) 和上び中心小体 (C)

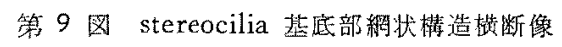

$A$; stereocilia 中心㷁糸, B; kinocilia 基底 小体, $\mathrm{M}$; microvili, $\mathrm{T}$; 閉鎖堤

符 10 因 Stereocilia. 基底部斜断像

$\mathrm{S}$; stereocilia, A; stereocilia 中心軸系,

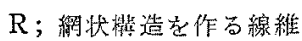

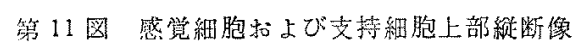

$\mathrm{S}$; stereocilia, $\mathrm{F}$; 感敩稩胞指状突起, $\mathrm{R}$;

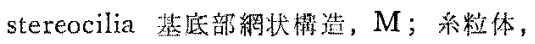

$\mathrm{T}$; 閉鏆堤

第 12 図壁感賞細胞蓝断像

$\mathrm{N}$; 核, $\mathrm{M}$; 系粒体， $\mathrm{E}$; 粗面小胞体， $\mathrm{n}$; nerve calix

管 13 図惑覚䄄胞上部横断像

$\mathrm{M}$; 系粒体, $\mathrm{R}$; 網状橧造, $\mathrm{T}$; 閉鎖堤 


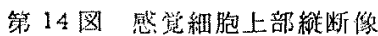

$\mathrm{S}$; stereocilia, $\mathrm{R}$; 網状筷造， $\mathrm{M}$; 系粒体， $\mathrm{G} ;$ ゴルデ野， $\mathrm{T}$; 閉鑟堤

第 15 図感覚上皮上部斜断像

$\mathrm{C}$; 感覚毛, $\mathrm{R}$; 網状膜

符 16图 同上強扗大像

$\mathrm{S}$; 支持細胞, $\mathrm{R}$; 絧状膜（閉鎖堤）

筷 17 因支持細胞上部綎断像

$\mathrm{T}$; 䦔鎖堤， $\mathrm{S}$; stereocilia, $\mathrm{M}$; microvili

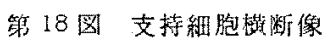

$\mathrm{N}$; 核, 几; 核小体, $\mathrm{M}$; 系粒体

籍 19 図支持細胞及び斬敫斜断像

$\mathrm{S}$; 支持細胞, $\mathrm{N}$; 支持緗胞核, $\mathrm{n}$; 粗索,

$\mathrm{M}$; 系粒体聘索

第 20 図感喾上皮下部斜断像

$\mathrm{N}$; 感喾細胞核, $\mathrm{N}^{\prime}$; 支持細胞核, $\mathrm{S}$; 感覚 細胞, $\mathrm{S}^{\prime}$; 支持細胞, $\mathrm{n}$; 軸索

第 21 図 nerve calix 綐断像

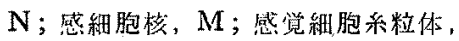
$\mathrm{n}$; nerve calix, $\mathrm{M}^{\prime}$; 軸案系粒体

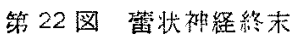

$\mathrm{N}$; 感觉紐胞核, $\mathrm{M}$; 感覚細胞系粒体, $\mathrm{n}$; 軸 索, $\mathrm{M}^{\prime}$; 韩索悉粒体

第 23 図 nerve calix 横断像 (2つ0感覚細胞を包九で いる像)

$\mathrm{N}$; 感觉細胞核, $\mathrm{M}$; 感覚細胞采粒体, $\mathrm{R}$; 感 営細胞小胞体, $\mathrm{n}$; nerve calix

第，24因基底膜附近斜断像

$\mathrm{S}$; 支持細胞, $\mathrm{S}^{\prime}$; 感賞細胞, $\mathrm{N}$; 朝案，

$\mathrm{B}$; 基底膜, $\mathrm{C}$; 毛紐血管

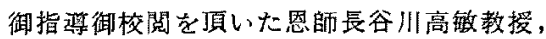
御教示を頂いた阪大第二解剖学教室小浜基次教

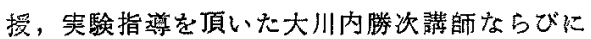

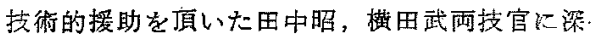
謝いたします

この論文の要旨は，第 58 回日再奥総会，策; $85,87,93,98,99,101$ 回日耳舆大阪地方会, 第 3 回耳奥咽堠科臨床会において発洼した。

(原街到着：昭和 35.6.14日一急載) 

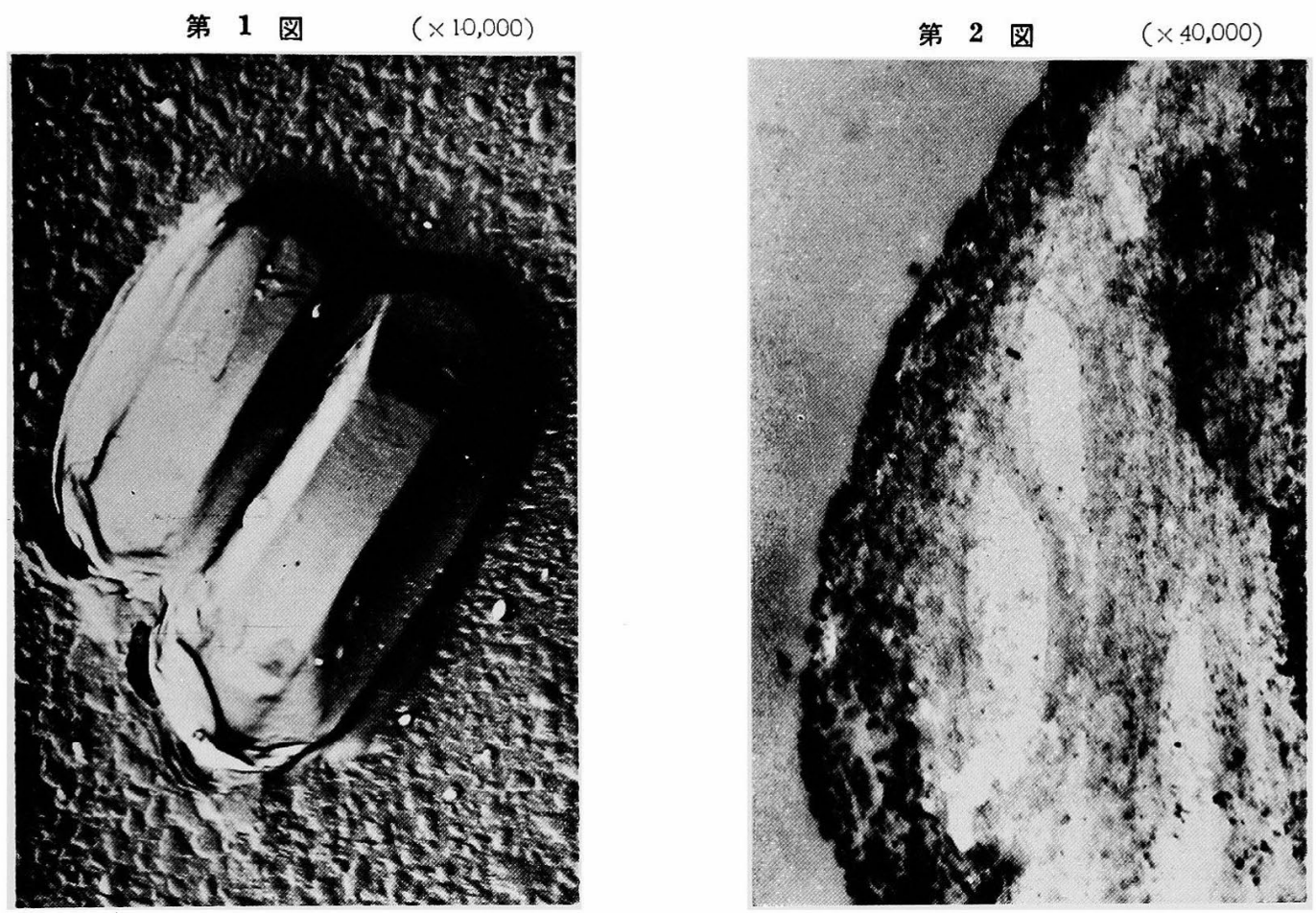

第 3 図

$(\times 30,000)$

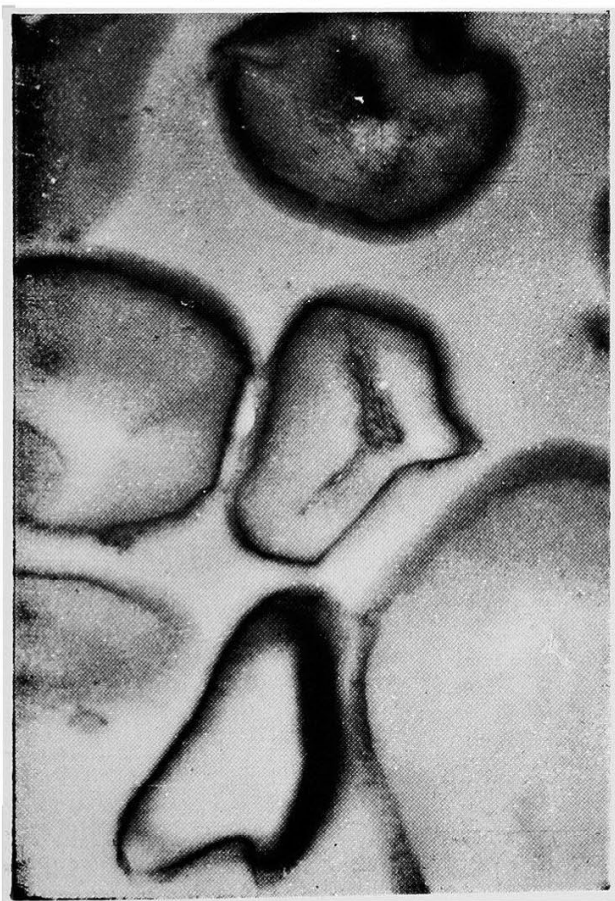

第 4 図

$(\times 5,000)$

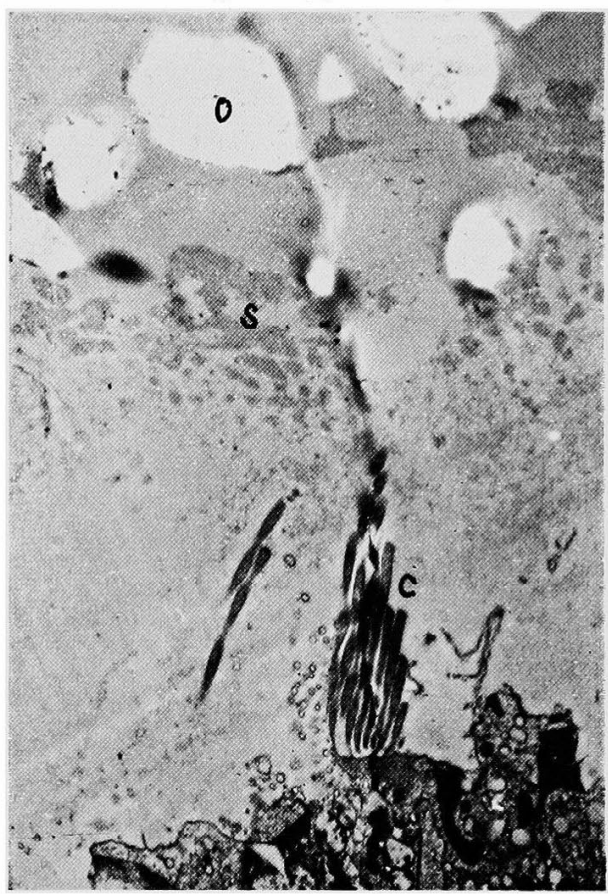


植松論文付図（I)
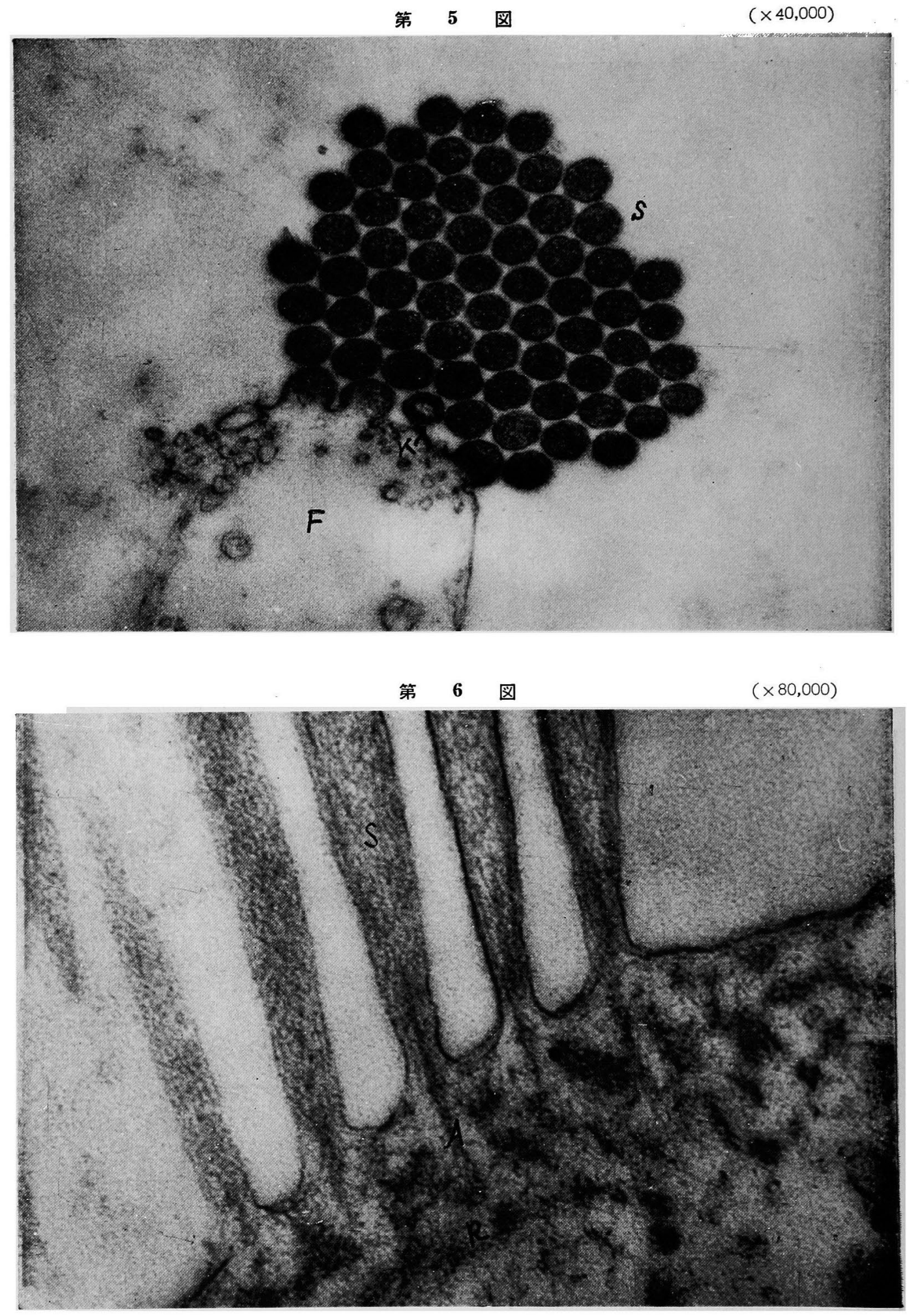
植松論文付図（III）
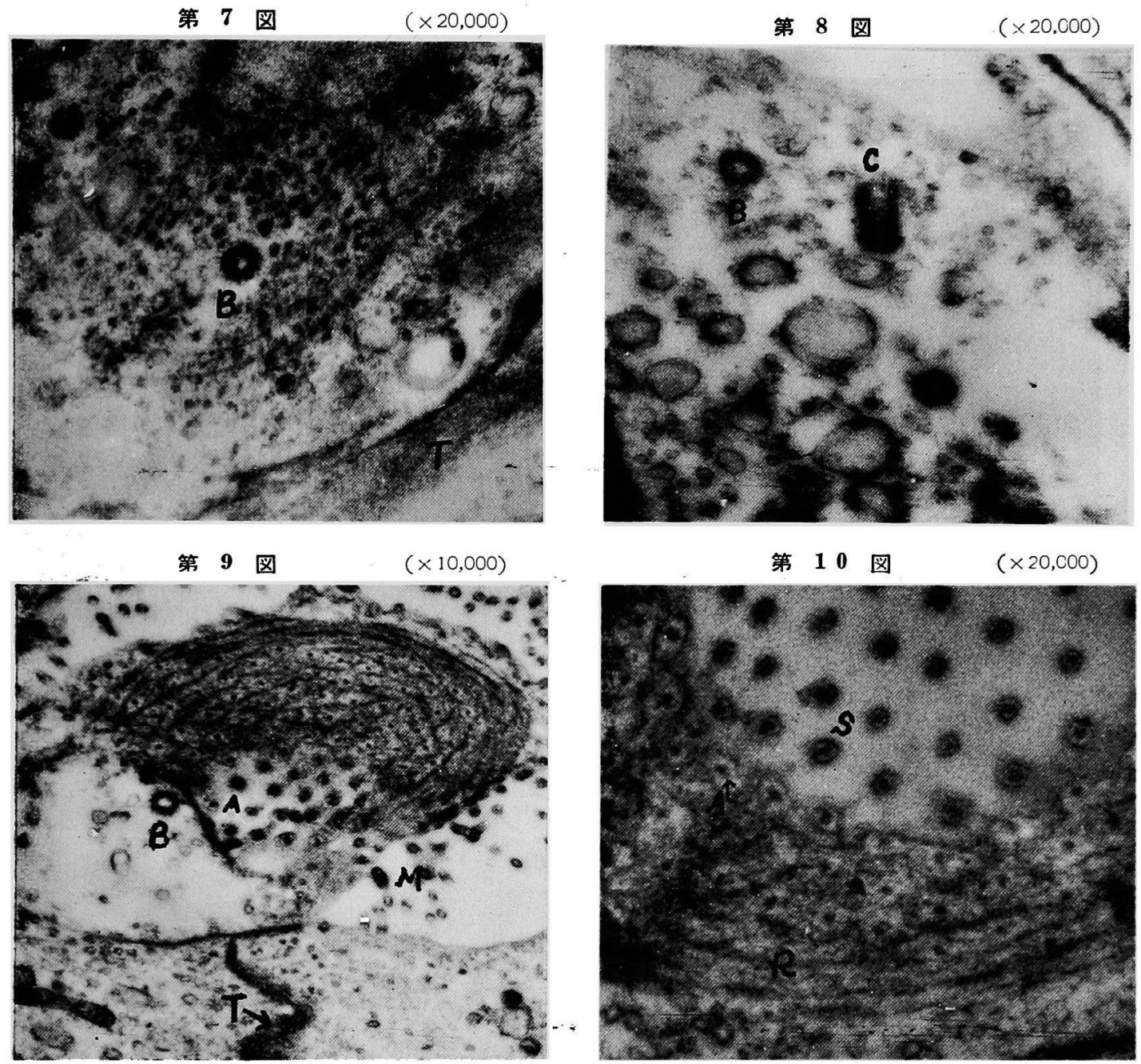

第 11 図

( $\times 15,000)$

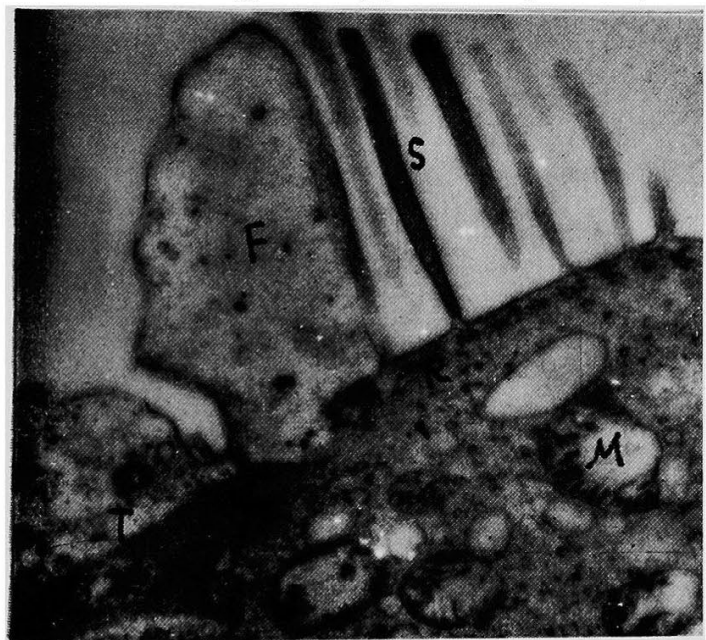

第 12 図

$(\times 7,000)$

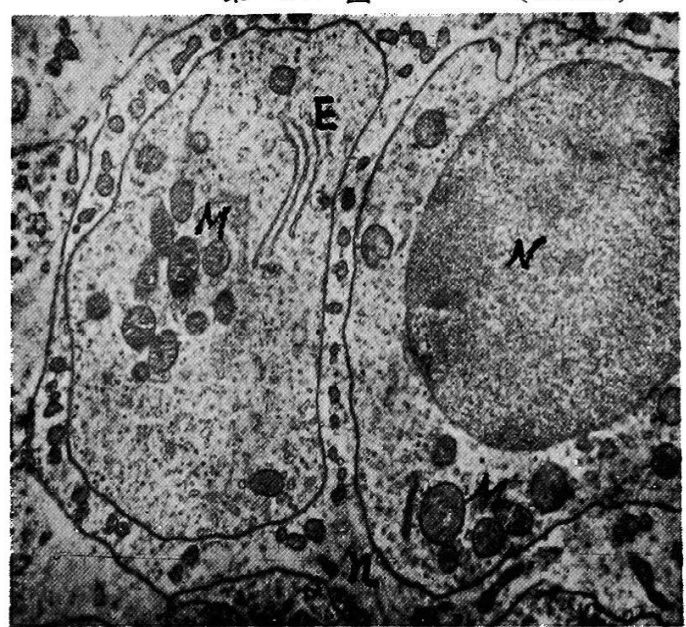


植 松論文付図（IV）

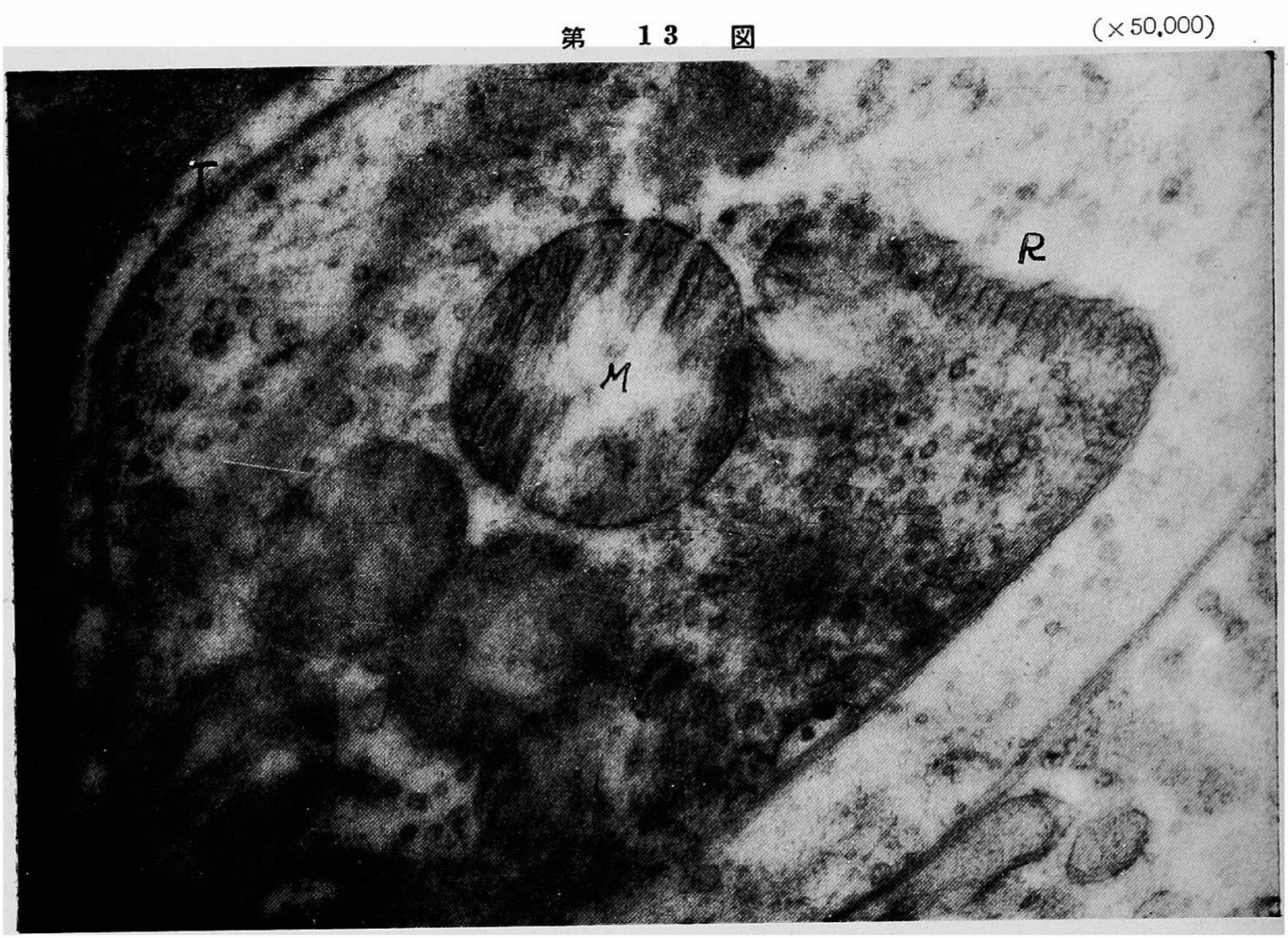

第 14 图

$(\ltimes 25,0 C 0)$

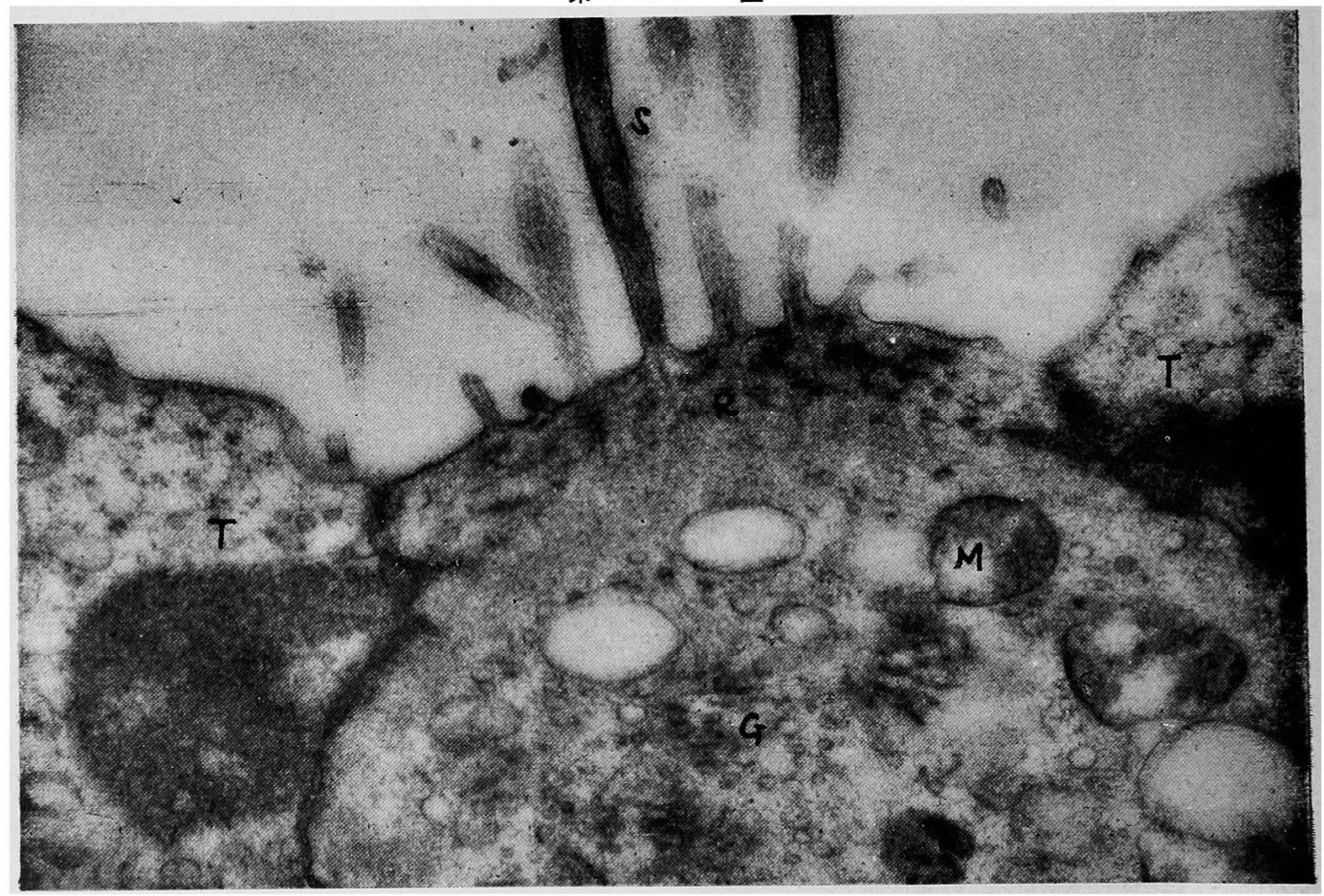


植 松 論 文 付図 (V)
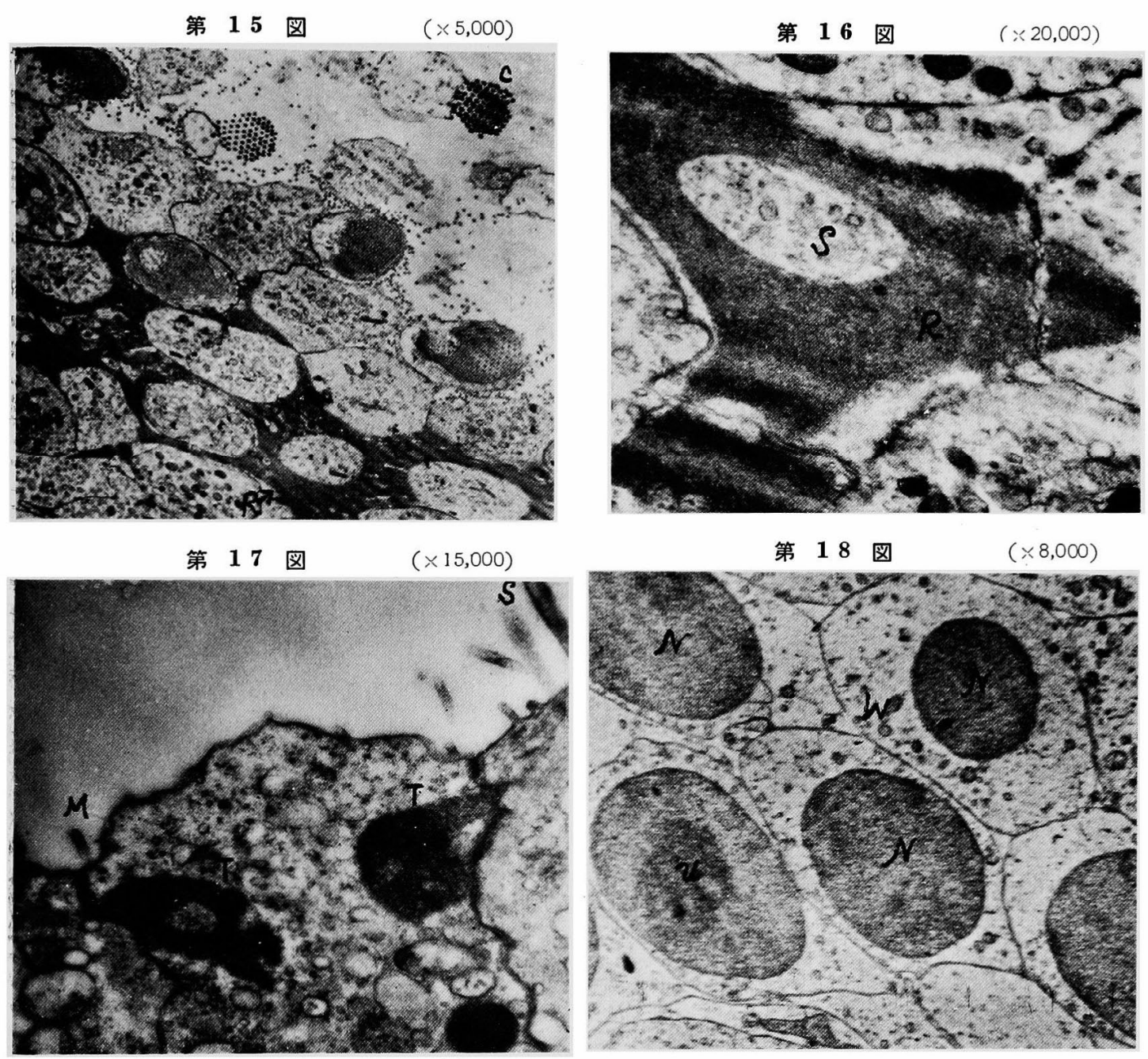

第 19 図

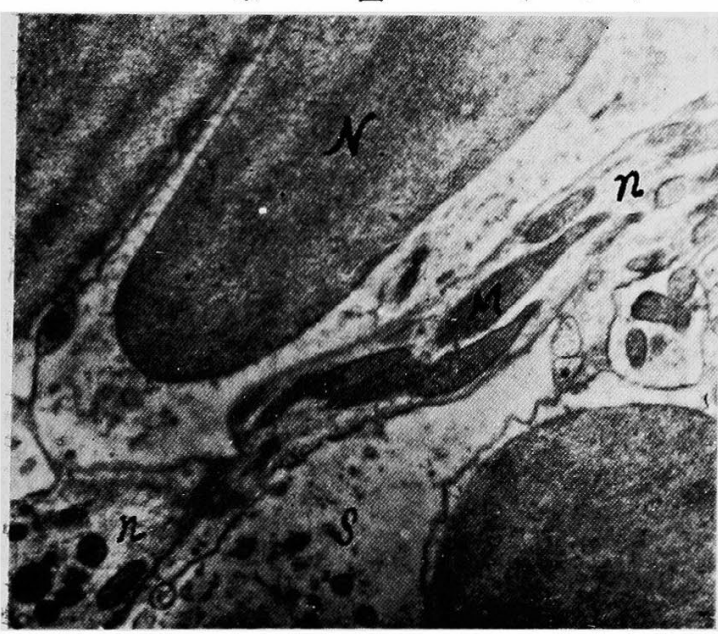

第 20 図

$(\times 3,000)$

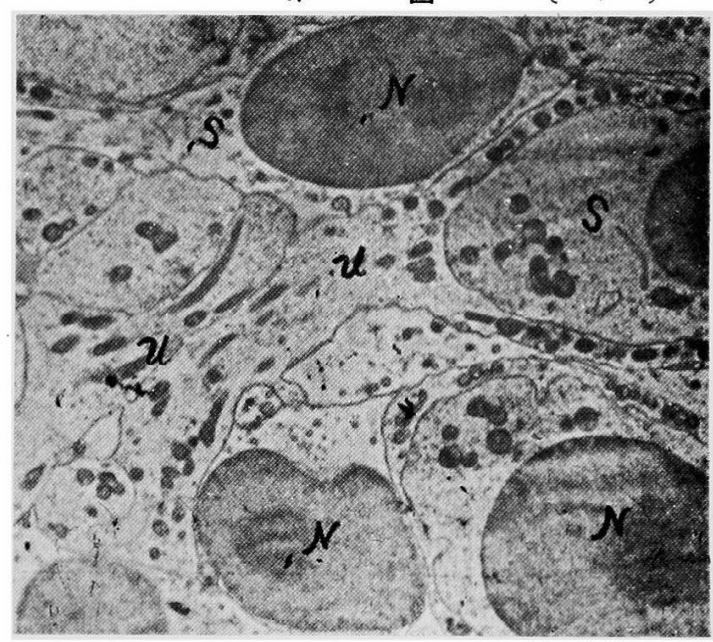


第 21 図

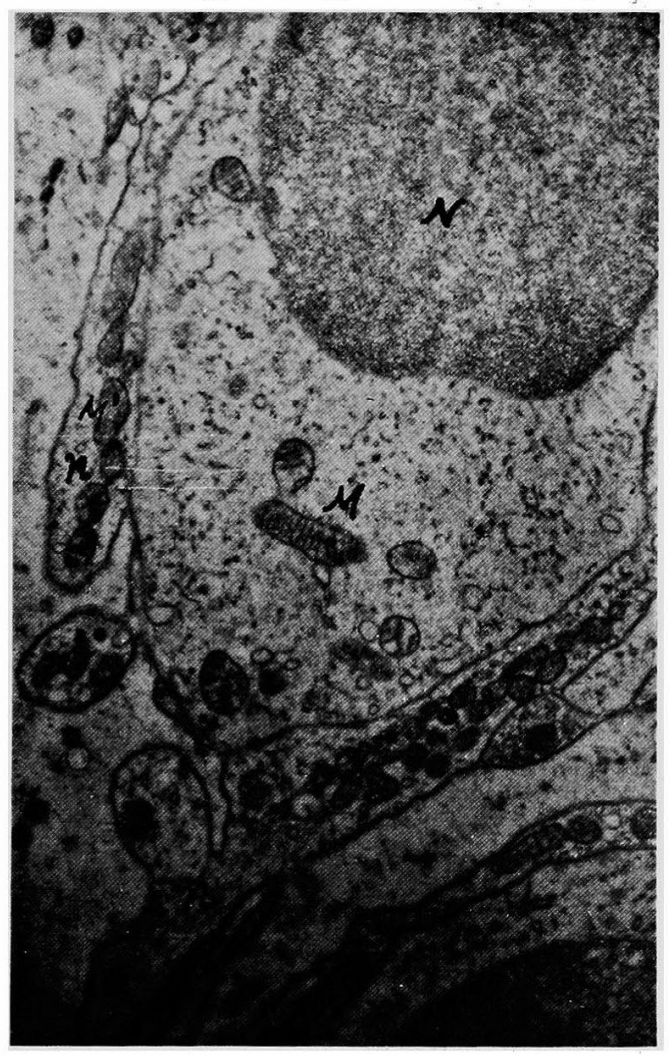

第 22 図( $(x 17,0 C 0)$

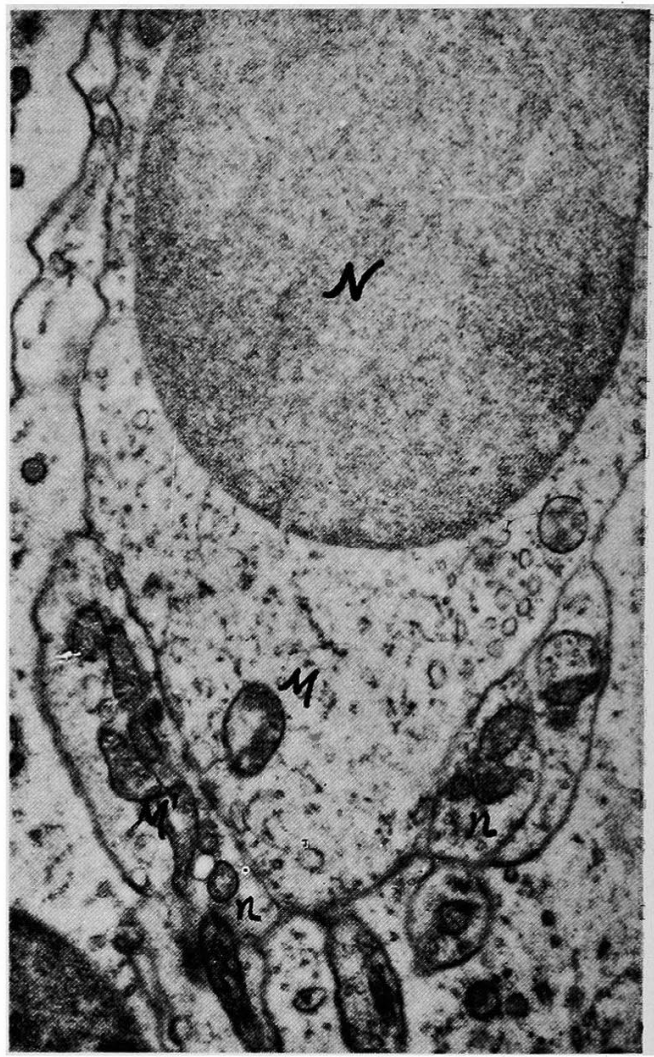

第 23 図

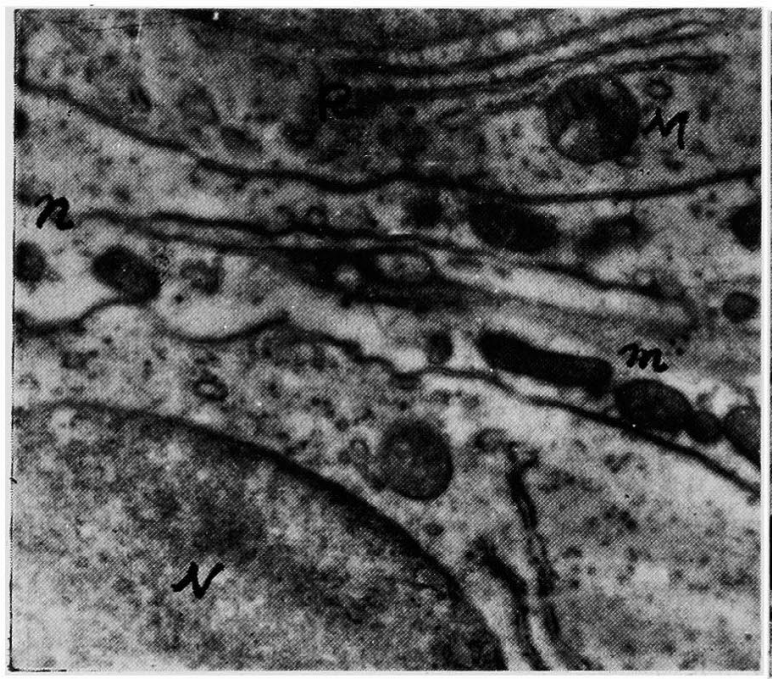

第 24 図

$(\times 5,000)$

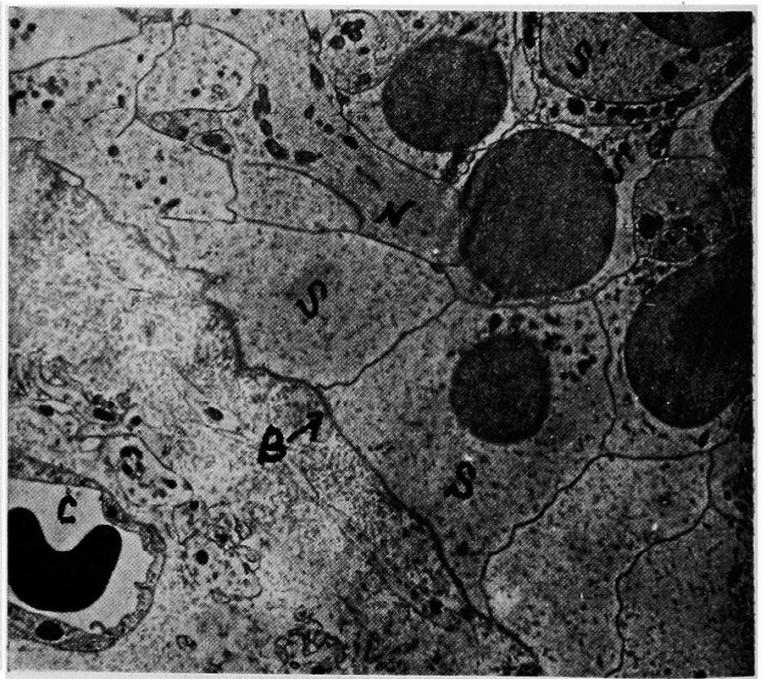

